\title{
Melanocytes in Development and Cancer
}

\author{
Audrey Uong ${ }^{1}$ and Leonard I. Zon ${ }^{1, *}$ \\ ${ }^{1}$ Stem Cell Program and Division of Hematology/Oncology, Children's Hospital Boston and Dana- \\ Farber Cancer Institute, Howard Hughes Medical Institute, Harvard Stem Cell Institute, Harvard \\ Medical School, Boston, Massachusetts.
}

\begin{abstract}
Genes and pathways essential to melanocyte development can also play crucial roles in melanoma formation. The vertebrate pigmentation system allows for a detailed study of normal cell development and the ways in which it may be subverted for cancer formation. Recent studies in mice and zebrafish, among other organisms, have illuminated several genes and pathways that are important in melanocyte development and specification and melanoma formation. A discussion of these genes and pathways in both normal and cancerous development can highlight several possible genetic targets to combat melanoma.
\end{abstract}

\section{Keywords}

Cell Development; Melanoma; Cancer Biology; Melanocytes

\begin{abstract}
Melanocytes are pigment-producing cells in the skin of humans and other vertebrates. A number of genes involved in melanocyte development and vertebrate pigmentation have been characterized, largely through studies of a diversity of pigment mutations in a variety of species. Embryonic development of the melanocyte initiates with cell fate specification in the neural crest, which is then followed by cell migration and niche localization. Many genes involved in melanocyte development have also been implicated in the development of melanoma, an aggressive and fatal form of skin cancer that originates in the melanocyte. Although early stage melanomas that have not spread to the lymph nodes can be excised with little risk of recurrence, patients diagnosed with metastatic melanoma have a high mortality rate due to the resistance of most tumors to radiotherapy and chemotherapy. Transformed melanocytes that develop into melanomas proliferate abnormally and often begin to grow radially in the skin. Vertical growth can then follow this radial growth, leading to an invasion through the basement membrane into the underlying dermis and subsequent metastasis. It is still unclear, however, how a normal melanocyte becomes a melanoma cell, and how melanoma utilizes the properties of the normal melanocyte and its progenitors in its progression. The goal of this mini-review is to highlight the role of melanocyte developmental pathways in melanoma, and to discuss recent studies and tools being used to illuminate this connection.
\end{abstract}

\section{Normal Melanocyte Development}

Melanocytes are derived from a group of highly migratory embryonic cells called the neural crest. The neural crest is induced at the time of gastrulation, in the zone between the neural and non-neural ectoderm (Erickson and Reedy, 1998), and gives rise to a number of cell

Corresponding Author: Dr. Leonard I. Zon, Karp Research Laboratories, $7^{\text {th }}$ Floor, 1 Blackfan Circle, Boston, MA 02115, zon@enders.tch.harvard.edu, Phone: (617) 919-2069, Fax: (617) 730-0222. 
types, including osteocytes, chondrocytes, and sensory neurons. Cell labeling studies indicate that neural crest cells are initially multipotent but gradually become lineagerestricted in developmental potential (Dorsky et al., 1998; Sieber-Blum and Cohen, 1980). In most cases, this potential is determined by its anatomic location. For example, cells in the mid- or hindbrain region form the cranial neural crest, which can develop into jaw cartilage and glia. The trunk neural crest gives rise to adrenal cells and sensory ganglia as well as pigmented melanocytes, although studies in avians have suggested a developmental plasticity that allows melanocytes to emerge from the cranial neural crest as well (Baker et al, 1997).

Early neural crest induction depends in part on intact BMP signaling, as $B M P 2$ knockout mice show an almost complete absence of neural crest derivatives (Kanzler et al, 2000). After induction, neural crest progenitor or stem cells undergo an epithelial-mesenchymal transition (EMT), in which a loss of adhesion to neighboring cells allows for cell migration. The Snail/Slug family of transcription factors is important in this process. Transcription of Snail coincides with the migration of neural crest progenitors, and Snail/Slug act to transcriptionally repress E-cadherin expression to allow cellular detachment and movement (Cano et al., 2000).

The Notch family of proteins plays at least three distinct roles in neural crest development. As evidenced by studies in the frog (Glavic et al., 2004) and in the chick (Endo et al., 2003), one role is to induce cranial neural crest development. Notch activation also plays an essential role in fate decisions of early progenitors, notably preventing cells in the trunk premigratory neural crest from taking on a neuronal fate and instead becoming unspecified neural crest precursors (Cornell and Eisen, 2002). This role of Notch signaling can be further confirmed by the zebrafish mindbomb or whitetail mutant, which harbors a mutation in the E3-ubiquitin ligase that impairs Notch signaling (Itoh et al., 2003). These mutants show an inclination towards a neuronal lineage and an almost complete absence of neural crest derivatives, including differentiated melanocytes, past the cranial region (Kelsh et al., 1996). It is uncertain whether Notch contributes to the proliferation or survival of these progenitors. Finally, Notch signaling is also important in maintaining the survival of adult melanocyte stem cells(Moriyama et al., 2006).

The development of a multipotent neural crest stem cell into a mature melanocyte has been well-studied, and data suggest that this process involves a bipotential glial-melanocyte lineage progenitor that develops into an unpigmented precursor cell called the melanoblast (Dupin et al., 2000). Commitment to the melanoblast stage usually occurs in the neural tube or after migration has started. Wnt signaling is important in promoting a cell fate decision towards melanoblasts and mature melanocytes as suggested by observations of Wnt deficient mice; virtually no melanoblasts are present in Wnt1; Wnt $3 a$ knock-out mice (Ikeya et al., 1997). Studies in fish also suggest that Wnt signaling mediates a fate switch between melanogenesis and gliogenesis through activated beta-catenin, as overexpression of betacatenin leads to an increase of melanocytes and a loss of glial derivatives (Dorsky et al., 1998). Lastly, Wnt signaling is required for terminal differentiation of melanoblasts (Dunn et al., 2000), suggesting that Wnt signaling plays many essential roles in melanocyte development.

\section{Melanocyte developmental pathways}

A number of studies have identified genes, such as mitf, Kit, and snail/slug, that are important for melanocyte development. These studies have elucidated genetic pathways that regulate several steps in melanocyte development. 
Mitf

Mitf is a melanocyte lineage-specific gene that encodes a transcription factor particularly important in melanocyte development. The gene was originally discovered in a mouse mutant in 1942 (Hertwig, 1942) and loss of mitf function results in an almost complete loss of melanocytes in mice and zebrafish (Lister et al., 1999). Mitf regulates the melanocyte lineage by activating several pigment-producing genes, such as $d c t$ and tyrosinase (Yasumoto et al., 1994). Fate mapping studies indicate that melanoblast survival is dependent on mitf (Hornyak et al., 2001); and the mechanism of survival involves the transcriptional upregulation of the anti-apoptotic gene bcl2 by mitf (McGill et al., 2002). This effect on survival may explain why animals deficient in mitf have defects in melanocyte numbers as well as melanin production.

Mitf is required for melanocyte specification (Widlund et al., 2003) and is regulated transcriptionally by several other genes known to support melanocyte development. Tcf/Lef binding sites which mediate Wnt signaling are found in the mitf promoter, and transcription factors such as beta-catenin and Sox 10 bind to and activate the mitf promoter. (Takeda et al., 2000; Bondurand et al., 2000; Lee et al., 2000; Potterf et al. 2000; Verastegui et al., 2000; Elworthy et al., 2003). Once expressed, the MITF protein can also be modified post translationally by phosphorylation, which modulates transactivation by MITF (Hemesath et al, 1998; Wu et al., 2000). In summary, a variety of signals are integrated to determine mitf expression and activity, which in turn determine melanocyte fate.

Kit

Kit is a type III receptor tyrosine kinase essential for melanocyte development in vertebrates. Kit plays a large role in pigmentation; humans heterozygous for a mutation in the $c-K I T$ gene have a pigmentation disorder called piebaldism (Giebel and Spritz, 1991). Mouse mutants for the $c$-Kit gene (Geissler et al., 1988) or its ligand steel/stem cell factor (Williams et al., 1990) also demonstrate varying degrees of pigmentation abnormalities as well as hematopoetic and germ cell defects. Analyses of melanocytes in Kit mutants suggest that Kit and the kit ligand have an important and complex role in melanocyte development, migration, and survival, which can differ according to species. In the mouse, kit mutants have fewer melanocytes, likely due to a failure in melanoblast migration (Wehrle-Haller and Weston, 1995); in the zebrafish kit mutant (a.k.a sparse), melanocyte specification occurs normally in the embryo; but migration fails and melanocytes undergo apoptosis (Parichy et al., 1999).

\section{Snail/Slug and Sox10}

The slug gene is an early marker of the neural crest lineage. It is part of the Snail family of DNA binding proteins, which are found in species from Drosophila to humans. In zebrafish, morpholino knockdown of Sox 10 results in a loss of Slug expression, and an overexpression of Sox10 shows an increase in Slug expression (Honore et al., 2003). Slug appears to be required to initiate neural crest migration, largely because it can repress $E$-cadherin and activate EMT, which is required for neural crest cell migration (Cano et al., 2000). When cells stop migrating and have reached their final destination in the embryo, Slug expression is lost (Meulemans et al., 2004).

\section{Endothelins}

Endothelins have a significant role in neural crest and melanocyte development. Endothelins are a family of vasoactive peptides (ET1, ET2, ET3) that bind to G-protein coupled receptors EDNRA or EDNRB. Their role in pigmentation was first described over a decade ago when knockout mice for the endothelin-B receptor (EDNRB) or its ligand, endothelin-3 
(ET3) showed an almost complete lack of melanocytes (Baynash et al., 1994). In the mouse, EDNRB is expressed in a subclass of premigratory and migratory neural crest cells (Pavan and Tilghman, 1994), and is only required during a small window of mouse melanoblast development and distribution. The loss of EDNRB during this window leads to an almost complete absence of melanocytes (Lee et al., 2003). As melanoblasts are already present at the beginning of this window, this suggests that although EDNRB may not be required in the early stages of melanoblast specification, it is essential for the survival and migration of these cells. The requirement of EDNRB appears to be species specific; whereas mouse mutants show embryonic abnormalities in melanocytes zebrafish ednrb mutants have normal embryonic melanocyte development and are deficient in a subclass of adult melanocytes that arise during metamorphosis (Johnson et al., 1995); (Parichy et al., 2000). Furthermore, ednrb may act in zebrafish in melanocyte specification rather than survival and dispersal of melanoblasts.

\section{Developmental Pathways in Melanoma}

Pathways involved in melanocyte development and proliferation are known to be subverted in the formation of melanoma. Mutations that overactivate BRAF and NRAS are found in nearly $65 \%$ and $20 \%$ of melanomas, respectively. These mutations appear to be somatically acquired, as wild-type BRAF and NRAS are found in normal tissue from melanoma patients. The most common BRAF mutation is a substitution of V600E, which results in a 700-fold overactivation of inherent BRAF kinase activity (Wan et al., 2004) that enhances cell division and survival. When expressed in zebrafish under the control of the mitf promoter, human oncogenic $\mathrm{BRAF}^{\mathrm{V} 600 \mathrm{E}}$ caused the formation of melanocyte clusters reminiscent of human nevi (moles); notably, many human nevi contain $\mathrm{BRAF}^{\mathrm{V} 600 \mathrm{E}}$ mutations. When expressed in $p 53$ loss-of-function mutant fish, the formation melanomas that histologically resembled human melanomas was observed (Patton et al., 2005). These data indicate cooperation between $B R A F$ and $p 53$ pathways, and suggests that $B R A F$ mutations are essential but not sufficient for melanoma formation.

Another common genetic mutation in melanoma is the loss of the CDKN2A locus, which encodes INK4a and ARF, both of which are tumor suppressor genes. INK4a deficiency leads to inappropriate activation of cyclinD/cdk4 and subsequent cell cycle progression. Overexpression of cyclinB and mutations in CDK4 that make it insensitive to inhibition by INK4a are also observed in melanomas. Although the p53 tumor suppressor is rarely mutated in melanoma (Daniotti et al., 2004), the frequent deletion of ARF suggests that p53 pathway activity is important in preventing melanoma development.

More recent studies in $\mathrm{BRAF}^{\mathrm{V} 600 \mathrm{E}}$ mouse models have provided further insights. Dhomen and colleagues showed that expression of $\mathrm{BRAF}^{\mathrm{V} 600 \mathrm{E}}$ in mouse melanocytes results in hyperpigmentation of the skin and nevus formation. These nevi contained senescent cells, demonstrating that $\mathrm{BRAF}^{\mathrm{V} 600 \mathrm{E}}$ induces senescence in vivo, $70 \%$ of these mice developed melanomas, and the authors suggest that the long latency of these tumors was due to an accumulation of additional genetic hits(Dhomen et al., 2009). Additional studies investigated genetic interactions with $\mathrm{BRAF}^{\mathrm{V} 600 \mathrm{E}}$, finding cooperativity loss-of-function mutations affecting Pten (Dankort et al., 2009) and p16 ${ }^{\text {INK4A }}$ and p53 (Goel et al., 2006).

MITF is overexpressed in many melanomas and an oncogenic role of this gene has recently been discovered (Garraway et al., 2005). MITF is proposed to act via a "lineage addiction" mechanism, whereby it allows cells to retain characteristics of the melanocyte lineage that are crucial to the development of a melanoma lineage-restricted tumor. MITF may do so by promoting the survival of tumor cells, as well as promoting inappropriate cell cycle progression. 
The role of $c$-KIT in human melanoma is complex. Rare acral and mucosal melanomas have mutations that overactivate Kit (Curtin et al., 2006; Antonescu et al., 2006). In initial trials, these tumors responded to the kit inhibitor imatinib mesylate (Hodi et al., 2008). Whereas these data suggest a dependence on Kit signaling, a majority of metastatic melanomas, particularly those that arise on intermittently sun exposed skin, downregulate Kit, and loss of Kit expression may be associated with increased invasion and metastasis. Therefore, the role of kit in melanoma formation and progression is may depend on melanocyte anatomical location.

A study by Gupta and colleagues supports a role for Slug in human melanoma invasion and metastasis (Gupta et al., 2005). In this study, properties inherent to the melanocyte lineage were proposed to mediate the migration of transformed cells, as transformed melanocytes gave rise to metastatic melanoma in a mouse xenograft, whereas similarly transformed fibroblasts only formed primary tumors and did not metastasize. Slug may have a role in the metastasis of these transformed cells, as knockdown of Slug in melanoma cells showed a significant decrease of metastatic potential and only a small decrease in primary tumor growth.

EDNRB is highly expressed in many human melanoma cell lines (Bittner et al., 2000); (Ross et al., 2000). When treated with an EDNRB-specific antagonist, BQ788, melanoma cells differentiated and stopped proliferating, possibly accompanied by an increase in cell death (Lahav et al., 1999). It is thought that EDNRB-mediated signaling may promote melanoma cell invasiveness in a number of ways, including by transcriptionally upregulating snail expression (Bagnato et al., 2004). EDNRB signaling may also cooperate with $B R A F$ activation, a central event in melanoma formation. In support of this model, a knockdown of oncogenic $\mathrm{BRAF}^{\mathrm{V} 600 \mathrm{E}}$ in melanoma cells demonstrated a reduction of colony formation and cell proliferation, which could then be partially rescued by ET-1, an endothelin peptide (Christensen and Guldberg, 2005).

\section{Future Directions}

The studies described above indicate that melanoma formation shares many characteristics with melanocyte development and regeneration, though there are still a number of questions to be answered. Clinical challenges to treating melanoma still remain, and prognosis for patients with metastatic melanoma continues to be very poor. Future directions include finding the right proteins and pathways to target in melanoma, and finding therapeutic compounds that more efficiently treat this devastating disease.

Studies in model systems can be used to great effect to address these issues. Genetic screens have been important in connecting novel genes to an interesting phenotype (Patton et al., 2001) and can be used to identify possible enhancers and suppressors of melanoma. RNAi screens are also powerful tools for loss-of-function genetic analysis in cells and model organisms (Boutrous et al., 2008). Chemical screens are useful for finding compounds that may target melanoma or prevent melanoma formation, which can lead to the discovery of chemotherapies that can combat melanoma. Tools that can aid these studies include the zebrafish strain casper, which is transparent, allowing a real-time and non-lethal visualization of tumor area and spread (White et al., 2008). Though significant progress has be made in understanding melanoma formation, further study of the genes and pathways involved in melanocyte development will be needed to develop better clinical therapies for melanoma patients and to improve their prognoses.

\section{Acknowledgments}

Contract Grant Sponsor: NIH; Contract Grant Number: DK53298-08. 
I would like to thank members of the Zon laboratory, especially Craig Ceol and Narie Storer, for their help in preparing this manuscript.

\section{References}

Antonescu CR, Busam KJ, Francone TD, Wong GC, Guo T, Agaram NP, et al. L576P KIT mutation in anal melanomas correlates with KIT protein expression and is sensitive to specific kinase inhibition. Int. J. Cancer. 2007; 121:257-264. [PubMed: 17372901]

Bagnato A, Rosano L, Spinella F, Di Castro V, Tecce R, Natali PG. Endothelin B receptor blockade inhibits dynamics of cell interactions and communications in melanoma cell progression. Cancer Res. 2004; 64:1436-1443. [PubMed: 14973117]

Baker CV, Bronner-Fraser M, Le Douarin NM, Teillet MA. Early-and late-migrating cranial neural crest cell populations have equivalent developmental potential in vivo. Development. 1997; 124:3077-3087. [PubMed: 9272949]

Baynash AG, Hosoda K, Giaid A, Richardson JA, Emoto N, Hammer RE, Yanagisawa M. Interaction of endothelin-3 with endothelin-B receptor is essential for development of epidermal melanocytes and enteric neurons. Cell. 1994; 79:1277-1285. [PubMed: 8001160]

Bittner M, Meltzer P, Chen Y, Jiang Y, Seftor E, Hendrix M, Radmacher M, Simon R, Yakhini Z, Ben-Dor A, et al. Molecular classification of cutaneous malignant melanoma by gene expression profiling. Nature. 2000; 406:536-540. [PubMed: 10952317]

Bondurand N, Pingault V, Goerich DE, Lemort N, Sock E, Le Caignec C, et al. Interaction among SOX10, PAX3 and MITF, three genes altered in Waardenburg syndrome. Hum. Mol. Genet. 2000; 9:1907-1917. [PubMed: 10942418]

Boutros M, Ahringer J. The art and design of genetic screens: RNA interference. Nat. Rev. Genet. 2008; 9:554-566. [PubMed: 18521077]

Cano A, Perez-Moreno MA, Rodrigo I, Locasio A, Blanco MJ, del Barrio MG, Portillo F, Nieto MA. The transcription factor snail controls epithelial-mesenchymal transitions by repressing E-cadherin expression. Nat. Cell boil. 2000; 2:76-83.

Christensen C, Guldberg P. Growth factors rescue cutaneous melanoma cells from apoptosis induced by knockdown of mutated (V 600 E) B-RAF. Oncogene. 2005; 24:6292-6302. [PubMed: 16007203]

Cornell RA, Eisen JS. Delta/Notch signaling promotes formation of zebrafish neural crest by repressing Neurogenin 1 function. Development. 2002; 129:2639-2348. [PubMed: 12015292]

Curtin JA, Busam K, Pinkel D, Bastian B, B C. Somatic activation of KIT in distinct subtypes of melanoma. J. Clin. Oncol. 2006; 24:4340-4346. [PubMed: 16908931]

Daniotti M, Oggionni M, Ranzani T, Vallacchi V, Campi V, Di Stasi D, et al. BRAF alterations are associated with complex mutational profiles in malignant melanoma. Oncogene. 2004; 23:59685977. [PubMed: 15195137]

Dankort D, Curley DP, Cartlidge RA, Nelson B, Karnezis AN, Damsky WE Jr, You MJ, DePinho RA, McMahon M, Bosenberg M. Braf(V600E) cooperates with Pten loss to induce metastatic melanoma. Nat Genet. 2009; 41(5):544-552. [PubMed: 19282848]

Dhomen N, Reis-Filho JS, da Rocha Dias S, Hayward R, Savage K, Delmas V, Larue L, Pritchard C, Marais R. Oncogenic Braf induces melanocyte senescence and melanoma in mice. Cancer Cell. 2009; 15(4):294-303. [PubMed: 19345328]

Dorsky RI, Moon RT, Raible DW. Control of neural crest cell fate by the Wnt signalling pathway. Nature. 1998; 396:370-373. [PubMed: 9845073]

Dunn KJ, Williams BO, Li Y, Pavan WJ. Neural crest-directed gene transfer demonstrates Wnt1 role in melanocyte expansion and differentiation during mouse development. Proc. Natl. Acad. Sci. USA. 2000; 97:10050-10055. [PubMed: 10963668]

Dupin E, Glavieux C, Vaigot P, Le Douarin NM. Endothelin 3 induces the reversion of melanocytes to glia through a neural crest-derived glial-melanocyte progenitor. Proc. Natl. Acad. Sci. USA. 2000; 97:7882-7887. [PubMed: 10884419] 
Elworthy S, Lister JA, Carney TJ, Raible DW, Kelsh RN. Transcriptional regulation of mitfa accounts for the sox 10 requirement in zebrafish melanophore development. Development. 2003; 130:28092818. [PubMed: 12736222]

Endo Y, Osumi N, Wakamatsu Y. Deltex/Dtx mediates NOTCH signaling in regulation of Bmp4 expression in cranial neural crest formation during avian development. Dev. Growth Differ. 2003; 45:241-248. [PubMed: 12828685]

Erickson CA, Reedy MV. Neural crest development: the interplay between morphogenesis and cell differentiation. Curr. Top. Dev. Biol. 1998; 40:177-209. [PubMed: 9673851]

Garraway LA, Widlund HR, Rubin MA, Getz G, Berger AJ, Ramaswamy S, Beroukhim R, Milner DA, Granter SR, Du J, et al. Integrative genomic analyses identify MITF as a lineage survival oncogene amplified in malignant melanoma. Nature. 2005; 436:117-122. [PubMed: 16001072]

Geissler, eN; Ryan, MA.; Housman, DE. The dominant-white spotting (W) locus of the mouse encodes the c-kit proto-oncogene. Cell. 1988; 55:185-192. [PubMed: 2458842]

Giebel LB, Spritz RA. Mutation of the KIT (mast/stem cell growth factor receptor) protooncogene in human piebaldism. Proc. Natl. Acad. Sci. USA. 1991; 88:8696-8699. [PubMed: 1717985]

Glavic A, Silva F, Aybar MJ, Bastidas F, Mayor R. Interplay between Notch signaling and the homeoprotein xiro1 is required for neural crest induction in Xenopus embryos. Development. 2004; 131:347-359. [PubMed: 14681193]

Goel VK, Lazar AJ, Warneke CL, Redston MS, Haluska FG. Examination of mutations in BRAF, NRAS, and PTEN in primary cutaneous melanoma. J. Invest. Dermatol. 2006; 126:154-160. [PubMed: 16417231]

Gupta PB, Kuperwasser C, Brunet JP, Ramaswamy S, Kuo WL, Gray JW, Naber SP, Weinberg RA. The melanocyte differentiation program predisposes to metastasis after neoplastic transformation. Nat. Genet. 2005; 37:1047-1054. [PubMed: 16142232]

Hemesath TJ, Price ER, Takemoto C, Badalian T, Fisher DE. MAP kinase links the transcripotion factor Microphthalmia to c-Kit signaling in melanocytes. Nature. 1998; 391:298-301. [PubMed: 9440696]

Hertwig P. Neue Mutationen und Koppelungsgruppen bei der Haus-maus. Z. Indukt. Abstamm. Vererbungsl. 1942; 80:220-246.

Hodi FS, Friedlander P, Corless CL, Heinrich MC, Mac Rae S, Kruse S, et al. Major response to imatinib mesylate in KIT-mutated melanoma. J. Clin. Oncol. 2008; 26:2046-2051. [PubMed: 18421059]

Hornyak TJ, Hayes DJ, Chiu LY, Ziff EB. Transcription factors in melanocyte development: distinct roles for Pax-3 and Mitf. Mech. Dev. 2001; 101:47-59. [PubMed: 11231058]

Honore SM, Aybar MJ, Mayor R. Sox10 is required for the early development of the prospective neural crest in Xenopus embryos. Dev. Biol. 2003; 260:79-96. [PubMed: 12885557]

Ikeya M, Lee SM, Johnson JE, McMahon AP, Takada S. Wnt signaling required for expansion of neural crest and CNS progenitors. Nature. 1997; 389:966-970. [PubMed: 9353119]

Itoh M, Kim chH, Palardy G, Oda t, Jiang YJ, Maust D, Yeo SY, Lorick K, Wright GJ, ArizaMcNaughton L, et al. Mind bomb is a ubiquitin ligase that is essential for efficient activation of Notch signaling by Delta. Dev. Cell. 2003; 4:67-82. [PubMed: 12530964]

Johnson SL, Africa D, Walker C, Weston JA. Genetic control of adult pigment stripe development in zebrafish. Dev. Biol. 1995; 167:27-33. [PubMed: 7851648]

Kanzler B, Foreman rK, Labosky PA, Mallo M. BMP signaling is essential for development of skeletogenic and neurogenic cranial neural crest. Development. 2000; 127:1095-1104. [PubMed: 10662648]

Kelsh RN, Brand M, iang YJ, Heisenberg CP, Lin S, Haffter P, Odenthal J, Mullins MC, van Eeden FJ, Furutani-Seiki M, et al. Zebrafish pigmentation mutations and the processes of neural crest development. Development. 1996; 123:369-389. [PubMed: 9007256]

Lahav R, Heffner G, Patterson PH. An endothelin receptor B antagonist inhibits growth and induces cell death in human melanoma cells in vitro and in vivo. Proc. Natl. Acad. Sci. USA. 1999; 96:11496-11500. [PubMed: 10500205] 
Lee M, Goodall J, Verastegui C, Ballotti R, Goding CR. Direct regulation of the Microphthalmia promoter by Sox 10 links Waardenburg-Shah syndrome (WS4)-associated hypopigmentation and deafness to WS2. J. Biol. Chem. 2000; 275:37978-37983. [PubMed: 10973953]

Lee HO, Levorse JM, Shin MK. The endothelin receptor-B is required for the migration of neural crest-derived melanocyte and enteric neuron precursors. Dev. Biol. 2003; 259:162-175. [PubMed: 12812796]

Lister JA, Robertson CP, Lepage T, Johnson SL, Raible DW. Nacre encodes a zebrafish microphthalmia-related protein that regulates neural-crest-derived pigment cell fate. Development. 1999; 126:3757-3767. [PubMed: 10433906]

McGill GG, Horstmann M, Widlund HR, Du J, Motyckova G, Nishimura eK, Lin YL, Ramaswamy S, Avery $\mathrm{W}$, ding $\mathrm{HF}$, et al. Bcl 2 regulation by the melanocyte master regulator Mitf modulates lineage survival and melanoma cell viability. Cell. 2002; 109:707-718. [PubMed: 12086670]

Meredith P, Sarna T. The physical and chemical properties of eumelanin. Pigment Cell Res. 2006; 19:572-594. [PubMed: 17083485]

Meulemans D, Bronner-Fraser M. Gene-regulatory interactions in neural crest evolution and development. Dev. Cell. 2004; 7:291-299. [PubMed: 15363405]

Moriyama M, Osawa M, Mak SS, Ohtsuka T, Yamamoto N, Han H, Delmas V, Kageyama R, Beermann F, Larue L, Nishikawa S. Notch signaling via Hes1 transcrioption factor maintains survival of melanoblasts and melanocyte stem cells. J. Cell Biol. 2006; 173:333-339. [PubMed: 16651378]

Parichy DM, Rawls JF, Pratt SJ, Whitfield TT, Johnson SL. Zebrafish sparse corresponds to an orthologue of c-kit and is required for the morphogenesis of a subpopulation of melanocytes, but is not essential for hematopoiesis or primordial germ cell development. Development. 1999; 126:3425-3436. [PubMed: 10393121]

Parichy DM, Mellgren EM, Rawls JF, Lopes SS, Kelsh RN, Johnson SL. Mutational analysis of endothelin receptor b1 (rose) during neural crest and pigment pattern development in the zebrafish Danio rerio. Dev. Biol. 2000; 227:294-306. [PubMed: 11071756]

Patton EE, Zon LI. The art and design of genetic screens: zebrafish. Nat. Rev. Genet. 2001; 2:956966. [PubMed: 11733748]

Patton EE, Widlund HR, Kutok JL, Kopani KR, Amatruda JF, Murphey RD, et al. BRAF mutations are sufficient to promote nevi formation and cooperate with p53 in the genesis of melanoma. Curr. Biol. 2005; 15:249-254. [PubMed: 15694309]

Pavan WJ, Tilghman SM. Piebald lethal (sl) acts early to disrupt the development of neural crestderived melanocytes. Proc. Natl. Acad. Sci USA. 1994; 91:7159-7163. [PubMed: 8041763]

Potterf SB, Furumura M, Dunn KJ, Arnheiter H, Pavan WJ. Transcription factor hierarchy in Waardenburg syndrome: regulation of MITF expression by SOX10 and PAX3. Hum. Genet. 2000; 107:1-6. [PubMed: 10982026]

Ross DT, Scherf U, Eisen MB, Perou CM, Rees C, Spellman P, et al. Systematic variation in gene expression patterns in human cancer cell lines. Nat. Genet. 2000; 24:227-235. [PubMed: 10700174]

Sieber-Blum M, Cohen AM. Clonal analysis of quail neural crest cells: they are pluripotent and differentiate in vitro in the absence of noncrest cells. Dev. Biol. 1980; 80:96-106. [PubMed: 7439536]

Takeda K, Yasumoto K, Takada R, Takada S, Wanatabe K, Udono T, Saito H, Takahashi K, Shibahara $\mathrm{S}$. Induction of melanocyte specific microphtalmia-associated transcription factor by Wnt-3a. J., Biol. Chem. 2000; 275:14013-14016. [PubMed: 10747853]

Verastegui C, Bille K, Ortonne JP, Ballotti R. Regulation of the microphtalmia-associated transcription factor gene by the Waardenburg syndrome type 4 gene, SOX10. J. Biol. Chem. 2000; 275:3075730760. [PubMed: 10938265]

Wan PT, Garnett MJ, Roe SM, Lee S, Niculescu-Duvaz D, Good VM, et al. Mutations of the BRAF gene in human cancer. Nature. 2004; 417:949-954.

Wehrle-Haller B, Weston JA. Soluble and cell-bound forms of steel factor activity play distinct roles in melanocyte precursor dispersal and survival on the lateral neural crest migration pathway. Development. 1995; 121:731-742. [PubMed: 7536655] 
White RM, Sessa A, Burke C, Bowman T, LeBlanc J, Ceol C, et al. Transparent adult zebrafish as a tool for in vivo transplantation analysis. Cell Stem Cell. 2008; 2:183-189. [PubMed: 18371439]

Widlund HR, Fisher DE. Microphtalamia-associated transcription factor: a critical regulator of pigment cell development and survival. Oncogene. 2003; 22:3035-3041. [PubMed: 12789278]

Williams DE, Eisenman J, Baird A, Rauch C, Van Ness K, March CJ, park LS, Martin U, Mochizuki DY, Boswell HS. Identification of a ligand for the c-kit proto-oncogene. Cell. 1990; 63:167-174. [PubMed: 1698553]

Wu M, Hemesath JJ, takemoto CM, Horstmann MA, Wells AG, Price ER, Fisher DZ, Fisher DE. c-Kit triggers dual phosphorylations, which couple activation and degradation of the essential melanocyte factor Mi. Genes Dev. 2000; 14:301-312. [PubMed: 10673502]

Yasumoto K, Yokoyama K, Shibata K, Tomita Y, Shibahara S. Microphthalmia-associated transcription factor as a regulator for melanocyte-specific transcription of the human tyrosinase gene. Mol. Cell. Biol. 1994; 14:8058-8070. [PubMed: 7969144] 